\title{
Prof. Cemal Arif Alagöz, Vefatının 30. Yılı Anısına
}

\section{Prof. Cemal Arif Alagöz, To Commemorate the 30th Anniversary of His Death}

\section{Harun Tunçel*a, Hikmet Çiçek ${ }^{b}$}

\begin{tabular}{l} 
Makale Bilgisi \\
\hline Biyografi \\
\hline DOI: \\
10.33688/aucbd.999554 \\
\hline Makale Geçmişi: \\
Geliş: 23.09.2021 \\
Kabul: 24.10.2021 \\
\hline Anahtar Kelimeler: \\
Alagöz \\
Cemal Arif Alagöz \\
Türk Coğrafya Kurumu \\
DTCF \\
Jips karst1 \\
Yaylacılık \\
\end{tabular}

\section{Article Info}

\begin{tabular}{l} 
Biography \\
\hline DOI: \\
10.33688/aucbd.999554
\end{tabular}

Article History:

Received: 23.09.2021

Accepted: 24.10 .2021

Keywords:

Alagöz

Cemal Arif Alagöz

Turkish Geographical

Society

Gypsum karst

Transhumance
$\ddot{O}_{z}$

Bu yazı Cemal Arif Alagöz’ü vefatının otuzuncu yılında anmak amacıyla hazırlanmıştır. Aynı zamanda onun hakkında genç coğrafyacılara ayrıntılı bilgi vermek de hedeflenmiştir Cemal Arif Alagöz, 1902 yılında Ístanbul'da doğmuş, 1991 yılında Ankara'da vefat etmiştir. Öğrenimini İstanbul'da görmüş, burada öğretmen okulundan mezun olup 1921 yllında ilkokul ögretmeni olarak göreve başlamış 1927 yılında yurt dışına gidinceye kadar bu görevi yapmıştır. Alagöz, üniversiteden mezun olduktan sonra, Fransa'ya gitmiş 1931 yllında Paris Üniversitesinden de diploma almış, 1931 yılında Ankara Gazi Terbiye Enstitüsünde göreve başlamıştır. 1933 yılında İstanbul Üniversitesi doçent kadrosuna atanmış, 1936 yılında Dil ve Tarih-Coğrafya Fakültesine geçmiştir. Burada 1943 yılında profesörlüğe yükseltilmiştir. 1944 yılından emekli olduğu 1972 yılına kadar bu bölümün başkanlığını da yapmıştır. Çeşitli bilimsel kuruluşlara üye olmuş ve onların faaliyetlerine katılarak her zaman desteğini sürdürmüştür. Birbirinden farkl pek çok konuda yayını olan Alagöz'ün özellikle yaylacılık ve karst konusundaki çalışmalarının coğrafya bilimi içinde ayrı ve önemli bir yeri vardır. Cemal Arif Alagöz, tüm hayatı boyunca mesleğini ön planda tutmuş, onun gelişmesi için çaba sarf etmiş olan müstesna bir bilim insanıdır.

\begin{abstract}
This article has been prepared to commemorate Cemal Arif Alagöz on the thirtieth anniversary of his death. At the same time, it is aimed to give detailed information about him to young geographers. Cemal Arif Alagöz was born in Istanbul in 1902 and died in Ankara in 1991. Alagöz went to France in 1927 and after graduating from Paris University in 1931, he started to work in Ankara Gazi Education Institute in 1931. He was appointed as an associate professor at Istanbul University in 1933 and transferred to the Faculty of Languages, History and Geography in 1936. He was promoted to professor there in 1943. He was also the head of this department from 1944 until his retirement in 1972. He became a member of various scientific organizations and always continued his support by participating in their activities. Alagöz, who has publications on many different subjects, has a special and important place in the science of geography, especially his studies on transhumance and karst. Cemal Arif Alagöz is an exceptional scientist who has prioritized his profession during all his life and made efforts to develop it.
\end{abstract}

\footnotetext{
*Sorumlu Yazar/Corresponding Author: Harun Tunçel, harun.tuncel@ bilecik.edu.tr

a Bilecik Üniversitesi, Fen-Edebiyat Fakültesi, Coğrafya Bölümü, Bilecik, Türkiye, http://orcid.org/0000-0003-1304-7177.

b Dicle Üniversitesi, Edebiyat Fakültesi, Tarih Bölümü, Diyarbakır, Türkiye, http://orcid.org/0000-0002-0098-4594.
} 


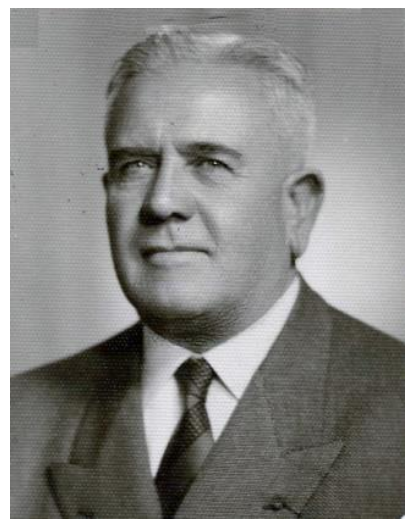

(1902, İstanbul- 23 Ağustos 1991, Ankara)

\section{Sunuş}

Prof. Cemal Arif Alagöz'ün vefatının ardından çeşitli anma yazıları yayınlanmıştır (Kayan, 1992; Köksal, 1993; Yalçınlar, 1993; Yücel, 1994) ayrıca muhtelif başka yayınlarda da hoca hakkında bazı bilgiler bulunabilir (Akkan, 1998; Erinç, 1973; Özçağlar, 2020; Tunçel, 2014; Tümertekin, 1998). $\mathrm{Bu}$ yazı hocanın vefatının otuzuncu yılı vesilesiyle, kaynaklar kısmında verilen yayınlardaki bilgilerin bir kısmı ile çoğunlukla hocanın arşivindeki bilgiler kullanılarak hazırlanmıştır. Yayınlarda bulunanlara ilave olarak, rahmetli eşi F. Zehra Alagöz hanımefendi tarafından Harun Tunçel'e devredilen, hocadan kalan evrak içinde yer alan ve bugüne değin her hangi bir yerde yazılmayan, yayınlanmayan pek çok bilgiye de ilk defa burada yer verilmiştir. Böylece, anmanın yanı sıra genç nesillere hoca hakkında ayrıntılı bilgi vermek de hedeflenmiştir. Alagöz hakkındaki anma yazıları ile diğerlerinin başlıcaları kaynakçada listelenmiş, özelliği ve önemi olan istisnai bir bilgi değilse metnin yazımında, ayrıca kaynağa atıf yapılmamıştır. Bu arada hocanın hayat hikâyesi ile ilgili olarak, sözü edilen yayınlarda kökeni belli olmayan lakin süregelen bazı eksikler, hatalı bilgiler belgelere dayalı olarak giderilmiştir.

\section{Adı, Doğum Yeri ve Tarihi Hakkında}

Cemal Arif Alagöz'ün adı, doğum yeri ve tarihi hakkında belgelerde birbirinden farklı bilgiler yer almaktadır. Cemal Arif, o tarihlerde Kastamonu Vilayetine bağlı olan, günümüz Sinop Boyabat kazasına bağlı olan, (Aşağı) Köprücek Köyü nüfusuna kayıtlıdır. Nüfus kayıtlarına göre, baba tarafından dedesi Mehmet, ninesi Ünzile, anne tarafindan dedesi Halit ve ninesi Hava'dır. Babası (Mehmet) Arif (1866-1927) efendi, annesi ise Mihriban (1877-1927) hanımdır. Cemal Arif Alagöz, ağabeyi Mehmet Ali'nin (1897-1966) ardından 1902 yılında İstanbul'da dünyaya gelmiştir. Doğum tarihi, Köksal ile Yalçınlar tarafından yazılan ve onlardan naklen alınan kısmi bilgilerle, Yiğit ve Tunçel tarafindan hazırlanan biyografilerde (Köksal, 1993; Yalçınlar, 1993; Yiğit ve Tunçel, 2017) 17 Mart 1902 olarak belirtilmekle birlikte, Fransa'dan aldığı diplomada doğum tarihi olarak 17 Ocak 1902 görülmektedir. 1943 yılında Dil ve Tarih-Coğrafya Fakültesi Dekanlığına sunmak üzere hazırladığı daktiloda yazılmış 'Cemal Arif Alagöz'ün Hal Tercümesi' başlıklı bir metinde hakkındaki yayınlarda doğum yeri için belirtilen Beşiktaş ifadesinden farklı olarak Nişantaşı kaydı düşülmüşsür. Alagöz, sözü edilen belgede ${ }^{1}$ "Babam Yıldız Sarayı ve daha sonra Büyük Millet Meclisi bahçıvan onbaşısı Arif 'A ğa'dır” şeklinde biraz da övünçle babasının görevine ve unvanına özellikle vurgu yapmıştır. Yaygın bilinen adı Cemal 
Arif olmakla birlikte, 1921 tarihli Darülmuallimin İbtidai Şehadetnamesi (İlkokul Öğretmenliği Diploması) ile 5 Teşrinievvel 1927 (8 Rebiulahir, 1345) tarihli, Fakülte Reisi ve Darülfünun Emin Vekili Köprüzade Mehmed Fuad imzalı, Darülfünun'dan aldığı diploma gibi resmi belgelerde, ismi sırasıyla, Cemaleddin ve Cemaleddin Arif olarak kayıtlara geçmiştir. Galatasaray lisesinde öğretmenken, İstanbul Tatbikat Mektebinde kendisi gibi öğretmenlik yapmakta olan, öğretmen lisesinden itibaren arkadaş1 olan, Mehmet Besim (Darkot) ile birlikte hazırladığı ve uzun yıllar ilkokullarda okutulan coğrafya kitaplarında kullandığı isim de Cemaleddin Arif'dir. Ancak Fransa'dan aldığı diplomada ve sonrasındaki diğer yayınlarında Cemal Arif adını kullanmayı tercih etmiştir.

\section{Eğitim Hayatı}

Doğum tarihinde olduğu gibi, hoca hakkında süregelen hatalı bilgilerden bir tanesi de ilköğretimi konusundadır. Var olan bilgiler eğitimini Afitab-1 Maarif ve Mekteb-i Ümit isimli özel ve Barbaros Nümune Mektebi adındaki devlet okullarında tamamladığı şeklindedir. Ancak hocanın kendi hazırladığı özgeçmişlerde Afitab-1 Maarif ve Mekteb-i Ümit isimleri geçmez. Cemal Arif Alagöz'ün beyanı ilk eğitimini İstanbul'da Ortaköy Cavid Ağa Mahalle Mektebi ile Beşiktaş’ta Barbaros Erkek Nümune Mektebinde yaptığı şeklindedir, diploması Barbaros Erkek Nümune Mektebindendir². Yukarıda sözü edilen hal tercümesindeki bilgilere göre eğitim hayatının devamı şöyle olmuştur. 1917 yılında İstanbul Erkek Muallim Mektebine (Erkek Öğretmen Okulu) girmiş ve buradan 1921 yılında ilkokul öğretmenliği diploması almıştır³. İstanbul Erkek Muallim Mektebinin Cemal Arif Alagöz’ün hayatında bir başka önemi daha vardır, burada okurken, ömrünün sonuna kadar en yakın arkadaşı ve dostu olacak Mehmet Besim (Darkot) ile tanışmıştır (Tuncel, 1991, 1992) ${ }^{4}$.

Alagöz, 1922 yılında Darülfünunun sınavlarını kazanmış ancak kendi ifadesiyle, öğretmenlik yapıyor olması onu bir müddet üniversite eğitiminden mahrum bırakmıştır. Biraz aşağıda ayrıntısıyla yazıldığı üzere, üniversite eğitimine devam etmek amacıyla ilk görevinden istifa ederek ayrılmış, öğretmenlik yaptığı okulları değiştirmiş ve nihayet amacına kavuşmuştur. Darülfünundaki öğrenciliği sırasında Théodore Lefebvre, Ali Macit (Arda), Hamit Sadi (Selen) gibi hocalardan dersler görmüş, 1927'de Darülfünun Coğrafya Şubesinden mezun olmuştur. Aynı yıl girdiği yurtdışı eğitimi sınavını kazanarak, üniversite tarafından 1927 y1lında Paris'te Sorbonne Üniversitesine gönderilmiş, buradaki eğitimi sırasında dönemin dünyaca ünlü coğrafyacılarından olan Emmanuel de Martonne ve Albert Demangeon gibi hocalardan dersler almış, onların etkisi daha sonrasında akademik hayatına doğrudan yansımıştır. 1931 yılında Paris Coğrafya Enstitüsünden mezun olarak ülkeye geri dönmüştür.

\section{İş Hayatı}

İstanbul Erkek Muallim Mektebini 1921'de üstün başarı ile bitiren ve 'İlk Mektep Muallimi' diplomasını alan Cemal Arif Alagöz, öğretmenlik mesleğine 1 Eylül 1921 de Beşiktaş'ta üç dershaneli Cevri Usta Okulu öğretmen vekilliği ile başlamış, aynı ay içinde, 23 Eylülde öğretmen tayin edilmiştir. Kazandığı sınavın ardından 31 Aralık 1921'de Ortaköy Darüleytamı (yetimler yurdu) öğretmenliğine kabul edilmiş, bu okulun lağvedilmesi üzerine sınıfıyla birlikte Balmumcu Darüleytamına nakledilmiştir. Fakat Coğrafya şubesine kayıtlı olduğu Darülfünuna devam edemediği için istifa ederek buradan ayrılmış ve önce Ortaköy Mecidiye Nümune, daha sonra Beyazıt Nümune Mektebi öğretmeni olarak çalışmıştır. 1924 yılının haziran ayında Galatasaray Lisesi muitliğine (muallim yardımcısı) üç ay 
sonra da ilk kısım Türkçe öğretmenliğine tayin edilmiş ve 1927 yılı Aralık ayında Fransa'ya gidinceye kadar üç buçuk yıl burada görev yapmıştır. Galatasaray'da görev yaparken bir taraftan Darülfünuna devam etmiş, diğer taraftan yabancı hocalarla dostluklar kurarak Fransızcasını geliştirmiş ve yanı sıra İngilizceyi öğrenmeye başlamıştır.

Darülfünundaki öğrenciliği sırasında, Mehmet Besim (Darkot) ile nöbetleşe, hocaları Prof. T. Lefebvre'nin derslerini tercüme etmişlerdir. Yine bu dönemde İstanbul Tatbikat Okulunda öğretmenlik yapmakta olan Mehmet Besim ile birlikte ilkokulların 3, 4 ve 5. sınıfları için 'Cumhuriyet Çocuklarına Yeni Coğrafya Dersleri’ kitaplarını yazmışır.

Fransa'da ikinci üniversite eğitimini başarıyla tamamlayıp döndüğünde, 12 Aralık 1931 tarihinde, Faik Sabri Duran'ın aynı zamanda müdürlüğünü de yaptığı Ankara'daki Gazi Terbiye Enstitüsü'nden ayrılması ile boşalan coğrafya öğretmenliğine ve buna ek olarak müdür muavinliği görevine tayin edilmiştir. Bu görevi sırasında ayrıca bir süre Ziraat Bankası Memurlar Kursunda, Ankara Kız Lisesinde ve Yapı Usta Okulunda da coğrafya dersleri vermiştir.

Gazi Terbiye Enstitüsü hocanın hayatında çok önemli bir yere sahiptir. Çünkü buradaki görevi sırasında kendisi gibi yurtdışında, İsveç’te beden eğitimi tahsili yapıp ülkeye dönmüş olan, beden eğitimi öğretmeni Zehra hanım ${ }^{5}$ ile tanışmıştır (Yücel, 1994: 207).

Cemal Arif Alagöz, Darülfünunun üniversiteye dönüştürüldüğü 1933 yılının son günlerinde, 26 Aralık 1933'te, İstanbul Üniversitesi Coğrafya Doçentliğine tayin olunmuş ve Ankara'dan ayrılmak zorunda kalmıştır. Bu ayrılma onun için zor olmuştur, zira evlidir, Ankara İstanbul arasında sürekli seyahat etmek zorunda kalacaktır. İstanbul Üniversitesinde üç yıl görev yapan Alagöz'ün kendi talebi üzerine, kuruluşunun üzerinden henüz bir yıl kadar zaman geçmiş olan Dil ve Tarih-Coğrafya Fakültesine, 14 Kasım 1936 tarihinde doçent olarak tayin edilmiştir. Bu tayin onun için, İstanbul'dan ayrılışı sebebiyle belki üzücü ancak aile birliğini tesis yönüyle de sevindirici olmuştur.

Dil ve Tarih-Coğrafya Fakültesinde göreve başladığında, kendisinin dışında üç kişi vardır. Bunlardan ilki Prof. Dr. Herbert Louis'dir. Louis'yi, fakültenin öğretim elemanı kadrosunu şekillendirmekte olan Erzurum Kongresi üyelerinden Cevat Dursunoğlu'na, Prof. Dr. [Norbert] ${ }^{6}$ Krebs tavsiye etmiştir. Berlin Üniversitesinden gelen Louis, Türkiye'den ayrıldığı vakte kadar bölüm başkanlığını da üstlenmiş̧tir. Diğer kişiler ise, güney kutbu araştırmacılarından [Erich Dagobert von] Drygalski’nin öğrencisi Doç. Dr. [İbrahim] Danyal Bediz ve Viyanalı coğrafyacı [Johann] Sölch'ün öğrencisi [Ahmet] Niyazi Çıtakoğlu'dur (Alagöz, 1975: 214, 216).

Alagöz, 26 Temmuz 1943 de aynı Fakültenin Coğrafya Profesörlüğüne yükseltilmiştir. Louis'nin 1943 yılında Köln Üniversitesine gitmesinin ardından 25 Mart 1944'de Coğrafya Enstitüsü Müdürlüğüne görevlendirilmiştir. 1946 yılı haziran ayında yürürlüğe giren Üniversiteler Kanunu ile enstitü iptal edilip yerine kürsüler kurulmuştur. Cemal Arif Alagöz bu yeni yapılanma içinde bir yandan Ülkeler Coğrafyası Kürsüsü ve diğer taraftan da Coğrafya Bölümü başkanlığını yaş haddi sebebiyle emekli olduğu 13 Temmuz 1972 tarihine kadar sürdürmüştür. 


\section{Emeklilik}

Cemal Arif Alagöz, aşağıda verilen yayın listesinde açıkça görüleceği üzere, emekliliği sonrasında da bilimsel üretime devam etmiş, toplantılara katılmış, tebliğler sunmuş ve bazı yayınlar yapmıştır. Hoca, İstanbul'a gittiğinde oradaki meslektaşlarıyla buluşarak sohbetler etmiştir ${ }^{7}$. Benzer şekilde Ankara Üniversitesindeki bölüm mensuplarını da yılda en az bir defa davet ederek ağırlaması ve onlarla yaptığı, hatıralarla süslü hoş sohbetler, henüz hayatta olan o zamanın genç asistanlarının hafızasında canlılı̆̆ını korumaya devam etmektedir.

Eldeki verilere göre Alagöz, meslek hayatı boyunca biriken kitap ve dergileri emekliliğinin ardından çeşitli kurumlara bağışlamıştır. Örneğin, hocanın evrakı içerisinde her hangi bir belge bulunamadığı için kesin bir tarih bilinmemekle birlikte, kuruluşunun ardından (Nisan 1975) Fırat Üniversitesine yüklüce bir kitap-dergi bağışı yapılmışıır, bu günümüze kadar söz konusu üniversite kütüphanesine yapılan en büyük bağıştır. Fırat Üniversitesi Merkez Kütüphanesi girişinde asılı olan teşekkür panosunda bağışlanan eser miktarının 3528 olduğu yazılıdır, ancak esefle belirtmek gerekir ki bağış̧̧ının adı Cemal Raif Alagöz şeklinde yanlış yazılımıştır. Bir diğer bağış ise Türk Tarih Kurumuna yapılmıştır. Önce 1 Mart 1979 tarihli bir yazı ile bağış yapma isteği iletilmiştir. Daha sonrasında da hazırlanan listelerdeki bilgilere göre, çoğunluğu kurumun ihtisas alanıyla ilgili olmak üzere 122 kitap ile 55 farklı derginin 482 sayısı buraya bağışlanmıştır. Elde kalan çok az miktardaki kitap ve dergi ise vefatı sonrasında eşi tarafından Dil ve Tarih-Coğrafya Fakültesi Coğrafya Bölümüne verilmiştir.

\section{Üyesi Olduğu Kuruluşlar, Diğer İdari Görevleri ve Aldığı Ödüller}

Cemal Arif Alagöz, hayatı boyunca mesleki kurumlara her zaman yakınlık göstermiştir. Kuruluşlarında görevler almış, üye olmuş, gelişmeleri maksadıyla onları desteklemiş bilimsel toplantılarına katılarak bildiriler sunmuştur. Bunlardan bilinen başlıcaları hakkındaki bazı bilgiler aşağıda verilmiştir.

Türk Coğrafya Kurumu, öncesi ve sonrası: Cemal Arif Alagöz'ün üyesi olduğu kurumlar arasında en çok emek verdiği, gelişmesi ve hayatta kalması için mücadele ettiği, Türk Coğrafya Kurumudur denilebilir. Alagöz, Türk Coğrafya Kurumunun kuruluş kararının alındığı, 6-21 Haziran 1941 tarihleri arasında Dil ve Tarih-Coğrafya Fakültesinde toplanan Birinci Coğrafya Kongresine bakanlık tarafından davet edilen bilim insanlarındandır. Hoca, bu kongrede çok önemli çalışmalar yapmış, kongrede Program ve Ders Kitapları Komisyonu ile Türkiye Coğrafyası Komisyonlarında görevler üstlenmiş konuya ilişkin raporlar hazırlamış, çeşitli konularda takrirler (önerge) vermiştir (Maarif Vekilliği, 1941: 111, 113, 127-128). Ayrıca yaylacılık konusunda 1939 yılında hazırladığı habilitasyonun bazı sonuçlarını yansıtan bir de rapor sunmuştur (Maarif Vekilliği, 1941: 150-157). Kongrenin son günü Türk Coğrafya Kurumunun kurulması hakkında bir önerge verilmiş (Maarif Vekilliği, 1941, 109) böylece kuruluş fiilen başlamıştır. Kurumun kurucu üyeleri arasında Cemal Arif Alagöz de vardır, ilk oluşturulan kurulda veznedar olarak görev almıştır (Anonim, 1943: 108, 110). Daha sonrasinda yapılan genel kurul toplantılarında da her zaman kurumun idarecileri arasinda bulunmuştur. 1948'de delege, 1952'de asbaşkan, 1958'de genel sekreter, 1961 ve 1964'de genel kurul üyesi olarak görevler üstlenmiştir (Ertek ve Özbakan, 2012: 32-36). Nihayet, Türk Coğrafya Kurumunun 1967 yılı Aralık ayında yapılan 8. Genel Kurulunda, Türk Coğrafya Kurumu Başkanlığı 
görevini üstlenmiştir. Bu görevi Türk Coğrafya Kurumu yönetim merkezinin İstanbul Üniversitesi Coğrafya Bölümüne nakil kararının da alındığı, 21 Mayıs 1987 tarihinde yapılan 16. Genel Kurula kadar sürdürmüş, bu tarihte başkanlık görevini Prof. Dr. İsmail Yalçınlar’a devretmiştir (Ertek ve Özbakan, 2012: 14-15). Böylece Cemal Arif Alagöz 1967-1987 yılları arasında yaklaşık yirmi yıl boyunca kurum idareciliğini üstlenerek, Türk Coğrafya Kurumu başkanlığını en uzun süreyle yapan kişi olmuştur. Alagöz ömrünün sonuna kadar kurumun neredeyse tüm bilimsel faaliyetlerine katılmıştır. Kurumun düzenlediği gezilere dâhil olmuş, meslek haftalarında ve kongrelerinde konuşmalar yapmıştır. Konuşmalarının bir kısmı bilimsel çalışmalarının sonuçlarıdır, bunların bazıları makale ve kitap olarak basılmıştır. Diğerleri ise uluslararası toplantılar, kurum faaliyetleri gibi meslekle ilgili bilgilendirme konuşmalarıdır ${ }^{8}$.

Doğu Anadolu Araştırma İstasyonu Müdürlüğü: Ankara Üniversitesi Dil ve Tarih-Coğrafya Fakültesi bünyesinde kurulan ve ne yazık ki hakkında yok denecek kadar az bilgi sahibi olduğumuz bu müdürlük, anlaşıldığı kadarıyla çok uzun ömürlü olamamış, atıl kalmıştır. Cemal Arif Alagöz’ün idarecisi olduğu bu müdürlüğün, bilinen tek faaliyeti, fakültede 1941-1945 yıllarında ilmi yardımc1 kadrosunda görev yapan Mahmut Sarıbeyoğlu'nun, H. Louis idaresinde başladığ fakat onun ayrılmasından sonra, Cemal Arif Alagöz danışmanlığında tamamlanan Aşağı Murat Bölgesinin Beşerî Coğrafyası adlı doktora tezini 1951 yılında bir numaralı yayın olarak kitaplaştırmış olmasıdır 9 .

Türkiye Jeoloji Kurumu Üyeliği: Türk Coğrafya Kurumunun ardından ülkemizdeki jeologlar da bir kuruluş altında bir araya gelme çalışmalarına başlamışlardır. Bu işe öncülük edenlerden ilki olan Ord. Prof. Hamit Nafiz Pamir, 10 Mart 1945 tarihli bir mektup ile Cemal Arif Alagöz'e ve mektubun mahiyetinden anlaşıldığı kadarıyla elbette diğer pek çok kişiye kurucu üye olmayı teklif etmiştir: Söz konusu mektup şöyledir ${ }^{10}$.

Sayın Bay:

Jeolojinin ve Jeoloji ile yakından ilgili meslek ve sahalartn memleketimizde mesut bir gelişme çı̆̆ırında gittikçe artan bir hızla ilerlediği ve bu muhtelif kollarda çalışan meslektaş sayısının daima artmakta bulunduğu iftiharla görülmektedir. Ancak belirli bir amaca hep birlikte gidilmesi, emeklerin boşa saçılmaması, şuurlu bir iş birliğiyle verimlerin artımlı olması, ihtiyaçların belirli yerlerde ve faydalı şekilde tatmin olunabilmesi için organize bir kurum halinde toplanmak, dost ve samimi bir ocakta kardeşçe bağların kolay ve sıkı olarak tesisile mümkün olabilir. İleri ve daima yeni, üstün ve sırf meslek ve arkadaş bağına dayanacak böyle bir "Jeoloji Kurumu”"nu hep birlikte meydana getirmek için sizin de yardımınızı ve kurucu üye olarak iştirakinizi arzu ve rica ediyoruz.

Jeoloji ve ona bağll meslek ve sahaların müstesna hususiyetlerinin zaten böyle bir topluluğu gerektirdiği ve mesleki dostlukların doğmuş bile bulunduğunu hatırlatır; teşebbüsün biran evvel gerçekleşmesini ve yakın bir gelecekte yararlı bir şekil almasını sizin de arzu edeceğinizden emin ulunmaktayiz.

Muvaffakat cevabinız alındiktan sonra kurumun ne şekilde tesis 
edileceği, nizamnamesi, toplama yeri ile tarihi ve kurucu üyelerin listesi ayrica bildirilecektir.

Cevabınızı bekler, derin saygı ve selamlarımı sunarım.

Jeoloji Enstitüsü Direktörü

Ord. Prof. Hamit N. Pamir

Bu nazik mektuba Cemal Arif Alagöz hocanın, Coğrafya Enstitüsü Müdürü sıfatılla 6 Nisan 1945 tarihinde cevaben yazdıkları ise şöyledir:

\author{
Sayın Ord. Prof. H. N. Pamir \\ İstanbul Üniversitesi Fen Fakültesi \\ Jeoloji Enstitüsü Müdürü \\ Istanbul
}

Bilhassa F. von Richthofen'den beri jeoloji ile sıkı bir bağ kurmuş ve bu sayede büyük ilerlemeler kaydetmiş bulunan coğrafyanın en yakın dostu olan jeolojinin memleketimizde gelişmesini hızlandırmak, çalışmalarını daha verimli kllmak amacıyle girişmiş bulunduğunuz klymetli teşebbüsü büyük bir memnunlukla öğrendim. Şimdiye kadar Türk Coğrafya Kurumu'nda jeolog dostlarımızın ve zatı âlilerinin pek değerli bir yeri vardı ve biz coğrafyacılar sizi ve jeolog arkadaşlarımızı daima kendimizden saymışıdır.

Himmetinizle, Türk Coğrafya Kurumu'na ilaveten, yeni kurulacak olan cemiyette jeolog ve coğrafyacıların yan yana ve ayn bağlllık ruhiyle çalışacaklarına şüphe etmiyorum. Bu itibarla kurucu üye olarak yanınızda yer almak teklifini bir iftihar vesilesi saydığımı ve bu feyizli işte bana düşen vazifeyi büyük bir zevkle başarmaya çalışacağımı bildirir, Size olan derin sevgi ve sayglarımı teyit ile şeref duyarım.

Coğrafya Enstitüsü Müdürü

\title{
Prof. (Cemal Arif Alagöz)
}

Bu yazışmanın ardından diğer coğrafyacılar olan Akyol, Gürsoy, İzbırak, Yalçınlar ve Yücel (Anonim, 1949: 148-151) gibi Alagöz de Türkiye Jeoloji Kurumuna ilk üye olanlar arasında 52 numara ile yerini almıştır. Türkiye Jeoloji Kurumunun 1949 yılında yapılan toplantısında 'Sivas, Elazı̆̆, Van Çevresinde Bazı Coğrafi Müşahedeler' başlıklı bir tebliğ sunmuş, bu daha sonra 'Bir Geziden Müşahedeler' başlığıyla kurum bülteninde yayınlanmıştır. Kurum üyeliği ömrünün sonuna kadar süren hocaya, 1974 yılında 25. Yıl Onur Belgesi ve 1979'da da otuzuncu yılı münasebetiyle Altın Çekiç Belgesi takdim edilmiş, hoca ayrıca bazı kurultaylarda haysiyet divanı üyeliği yapmıştır.

Türkiye Mağara Araştırmaları Cemiyeti üyeliği: Cemal Arif Alagöz hocanın mesleki kuruluşlara verdiği önemin göstergelerinden birisi de bu cemiyet üyeliğidir. Mağara bilimine hep özel bir önem vermiş olan genç arkadaşı jeolog Temuçin Aygen'in (İstanbul 1921- Antalya 2003) 1964 y1lında kurduğu Türkiye Mağara Araştırma (Speleoloji) Cemiyeti’ne ${ }^{11}$, karst araştırmalarına olan 
ilgisinin de etkisiyle olsa gerek, hemen 7 numara ile üye olmuştur.

Türkiye Jeomorfologlar Derneği Fahri Üyeliği: Cemal Arif Alagöz bir diğer mesleki kuruluş olan Türkiye Jeomorfologlar Derneğine de her zaman destek olmuştur. 1964 yılında kurulan derneğin, ömrü boyunca neredeyse tüm kurultaylarına katılmış, bunların bazılarında konferanslar vermiş, bunlardan "Karst Olayları Üzerine Yeni Bir Müşahede Antalya Liman Koyağı" adlı konferansı Jeomorfoloji Dergisinin 5. sayısında yayınlanmıştır.

Cemal Arif Alagöz hocanın yukarıda değinilenlerin dışında başka bazı üyelikleri de vardır. Bunların büyük bölümünün başlangıç zamanları ne yazık ki hocanın evrakı içerisinde belirtilmemiştir, ancak sadece liste olarak bulunmaktadır. Bu üyeliklerin Türkiye'deki kurumlarda olanlarının listesi şöyledir: Millî Eğitim Bakanlığı Öğretmen Kitapları Komisyonu, Türkiye Meteoroloji Kurumu ${ }^{12}$ İdare Heyeti, Türkiye Tabiatını Koruma Cemiyeti İstişare Kurulu, Türk İktisat Cemiyeti, Türk-Fransız, Türkİngiliz, Türk-Amerikan kültür dernekleri üyelikleri, Atatürk Üniversitesi Bilimsel Araştırmalar Enstitüsü şeref üyeliği, Milli Kütüphaneye Yardım Derneği Üyeliği ve 1972 yılına kadar başkanlığı. Başka ülkelerdeki kurumlara üyelikleri ise şunlardır: Paris Coğrafya Cemiyeti Fahri Üyeliği (20 Mart 1958), Münih Coğrafya Cemiyeti Muhabir Üyeliği (20 Kasım 1969), Milletlerarası Coğrafya Birliği Türkiye Komitesi Sekreterliği, Milletlerarası Coğrafya Birliği Coğrafya Öğretimi Komisyonu Üyeliği, UNESCO Genel Merkezi Kurak Bölgeler İstişare Komitesi Üyeliği, National Geographic Society üyeliği.

Bunların dışında hoca, UNESCO'nun 1950'de Kanada'da tertiplenen Coğrafya Seminerinde 3 Temmuz 1950-24 Ağustos 1950 tarihleri arasında grup başkanlığı, 1953 Uluslararası Coğrafya Kongresinde Seksiyon Başkanlığı yapmıştır. Cemal Arif Alagöz’e 5 Aralık 1957 tarihinde, Fransa adına 63.222 numaralı onur belgesi takdim edilmiştir.

\section{Bilimsel Maksatlı Seyahatleri}

Alagöz gerek yurtdışında ve gerekse ülkemizde pek çok yeri inceleme gezip görme ve inceleme gayreti içerisinde olmuş bunlara dair titizlikle kayitlar tutmuştur. Daha öncesinde bahsedilen hal tercümesinde verdiği bilgilere bakılırsa, yurtdışında eğitim gördüğü sırada her firsatı değerlendirmeye çalışmış, diğer amaçlarla yurtdışına çıkışlarında da mümkün olduğunca farklı yerleri görmeye gayret etmiştir. O dönemlere ilişkin olarak kendi ifadeleriyle yaptığı seyahatler şunlardır:

"Meslek hayatımda coğrafya müş̧ahede ve araştırma gezilerine önem verdim. Paris'te iken Enstitünün tertip etmiş olduğu bütün gezilere, istisnasız, iştirak ettim. Böylece, Paris Coğrafya Kongresinin tertiplemiş olduğu iki büyük gezi de dahil olduğu halde bu seyahatlerde Massif Central'i, Causse'ları, Burgonya'yl, Paris havzasını, Ron vadisini, bütün Côte d'Azure'ü ve Korsika'yl, doğu Pireneleri ve Italya sinırına kadar Dauphine Alplerini gezdim. Besim Darkot ve Ahmet Ardel'le birlikte Alzas ovasini, Kolonyaya kadar Rayn nehri boyunu, Belçika'da Brüksel, Anvers ve Ostende'ı gördüm. 1931 de Ingiltere'de iki aylık: tatil ikametim sirasinda Oxford'a kadar Londra çevresini ziyaret ettim.

1938 de Köstence-Polonya-Almanya üzerinden Amsterdam'a gittim 
ve Kongrenin muhtelif gezilerine katılarak, kuzey kısmı hariç bütün Felemenk'i gördüm. Kongre dönüşü Belçika ve Kuzey Fransa'dan geçerek Paris'e geldim. Besim Darkot ve Ahmet Ardel'le Strasburg'ta buluştuk. Basel ve Luzern'i gördükten sonra Quatre Cantons gölü yoliyle Ísviçre'den geçip Kuzey Italya'ya indik. Birlikte Milano'yu, Floransa'yl, Roma ve Napoli'yi, Brindizi'yi ve Yunanistan'da Pire ve Atine'yi ziyaret ettik. Nihayet 1949 Lizbon Kongresi münasebetiyle de Portekizin büyük bir kısmını ve dönüşte Ispanya'nın Madrid, Sevilla, Grenada, Malagga, Barcelona şehirlerini gezdim; İtalyanın Genova limanını gördüm”.

Cemal Arif Alagöz, daha sonra da katıldığı uluslararası toplantıların gezilerine mutlaka dahil olmuş yahut tatil maksadıyla yurtdışına yaptığı seyahatlerde coğrafi gözlemler yapmayı ihmal etmemişstir.

Benzer şekilde Cemal Arif Alagöz, yurtiçinde de çeşitli vesilelerle seyahatler yapmış, ülkenin neredeyse her tarafını görme firsatı elde etmiştir. Sivas ve çevresi, Karadeniz dağları ve Toroslar gibi bir kısmını, kendi bilimsel çalışmaları için yaptığı seyahatlerde dolaşmıştır. Ülkenin geri kalan diğer pek çok yerlerini de Milli Eğitim Bakanlığının düzenlediği Gezili Coğrafya Kursu, Meslek Haftası, Coğrafya Bölümü öğrenci gezisi gibi farklı amaçlarla düzenlenmiş seyahatlerde görmüş ve inceleme fırsatı elde etmiştir. Alagöz, yurtiçinde yaptığı bütün seyahatlerin güzergâhlarını dilsiz bir Türkiye haritası üzerinde farklı renklerde kalemlerle çizerek kaydetmiştir. Rotaları gösteren hatların üzerine ayrıca başlangıç ve bitiş yerlerini yazarak belirtmiş, her birisi için seyahat tarihlerini de kaydetmiştir ${ }^{13}$. Cemal Arif Alagöz, 1948 yılı Ekim ayında kurulmuş olan Pedagoji Cemiyeti'nin yayınlamaya karar verdiği 'Pedagoji Ansiklopedisi’ için kendisinden istenen özgeçmiş için hazırladığı 10 Ağustos 1949 tarihli cevap yazısında, yurtiçinde o vakte kadar gördügü yerleri şöyle anlatmıştır:

“Memleketimizde 1931'den beri tetkik ve ögretim amaçlarıle birçok geziler yaptım Yeşilırmak'tan Aşağı Sakarya'ya kadar bütün kuzey Anadolu'yu, kıyllariyle birlikte -ve bazı kısımlarını birkaç defa-dolaştım. Doğu Karadeniz, Akdeniz kıyılarını gördüm. Trakya'da İstanbul-UzunköprüKeşan-Gelibolu güzergâhını, Keşan ve Gelibolu'yu, bütün Gelibolu Yarımadası'nı, Çanakkale'yi tanıyorum. İç Anadolu'yu Batı Anadolu'yu (Muğla tarafları hariç) ziyaret ettim. Muhtelif yerlerde fazlaca da kaldım Orta ve Batı Torosların büyük bir kısmını gezdim. Maraş, Gaziantep ve Kilis’i gördüm; bütün Hatay'ı dolaştım. Ankara doğusunda Sivas'a kadar olan bölgeyi, kısmen Sivas-Malatya arasının, Diyarbakır çevresini, Beşiri petrol alanını tanıdım ve Erzurum doğusunda Kars, Kağızman, Ardahan, Artvin çevrelerinde araştırmalar yaptım. Bu seyahatlerin bir kısmı Prof. Chaput'ye, diğer bir kısmı Prof. Louis'ye refakat ederek; birçoğu da şahsen, arkadaşlarım ve ögrencilerimle birlikte yapılmıștır. Prof. Louis ile ve coğrafya enstitüsü öğrencileriyle Medetsiz'e (3585 metre) Antalya'nın Beydağı'na (3080 metre), Barla dağına (2700 metre), Bolu'nun Köroğlu dağına (2300 metre), iki defa da Ilgaz'a (2560 metre) çıktık. Biri Prof. 
Lefebvre ile olmak üzere üç kere Uludağ'a (2500 metre) çıklş yaptım. Münferiden Palandöken, Allahüekber (3200 metre), Toroslarda Geyik dă̆ (2900 metre) zirvelerine tırmandım. Ankara vilayetini tamamen gezdiğim gibi, Milli Eğitim Bakanlığının talebi üzerine ve mali-idari yardımı ile Temmuz-Ăgustos 1947'de orta ögretimde çalışan arkadaşlar için tertib ettiğimiz gezili coğrafya kursunda İstanbul Üniversitesi Coğrafya profesörleri arkadaşlarımla işbirliği yaparak Doğu ve Kuzey Anadolu'yu yeniden gördüm. Öyle sanıyorum ki memleketimizin 3/4 ünü görmüş bulunuyorum."

Cemal Arif Alagöz, emekliliğinden sonra hazırladığı bir yayınında yurtiçi seyahatleri ile ilgili olarak son derece ayrıntılı bilgiler vermiştir, burada yer almayan bir kısım bilgiler de başka bazı yayınlarda dağınık listeler halinde bulunabilmektedir, bu sebeple burada konuyla ilgili yeniden vermek gereksiz olacaktır, ancak ilgilenenler bunlara bakabilirler ${ }^{14}$.

\section{Başlıca Araştırmaları}

Aşağıda bilinen ve bulunabilen yayınlarının bir listesi sunulan Cemal Arif Alagöz'ün yayınları hakkında bazı öz bilgiler vermeden önce hemen belirtmek gerekir ki, hocanın kimi çalışmaları, sadece tebliğ olarak kalmış ve yayınlanmamışır. Sayıları bir hayli olmakla birlikte bunlara örnek olarak 'Türkiye'de Dağınık Yerleşmeler', 'Elmadağ' da Yaylacılık', 'Van Reşadiye Polyesi ${ }^{15}$ verilebilir.

Cemal Arif Alagöz’ün ilk yayınları, henüz akademik hayata başlamadan önce, öğretmenlik yaptığı dönemlerde Mehmet Besim (Darkot) ile birlikte ilköğretim 3-5. sınıflar için hazırladıkları kitaplardır. İlk baskısı 1926 yılında yapılan bu kitaplar 17 yıl boyunca ilkokullarda ders kitabı olarak okutulmuş, daha sonrasında 1943 Yılında Talim Terbiye Kurulu komisyonunun kitabı 'seviye üstü' bulması gerekçesiyle bu durum son bulmuştur. Komisyonun bu kararına Darkot ve Alagöz ayrı ayrı, ayrıntılı açıklamalarla gerekçeli itirazlar yapmışlarsa da ne yazık ki komisyon bu itirazlarını kabul etmemiştir.

Alagöz'ün akademisyen olarak görev yaptığı dönemdeki yayınları topluca değerlendirilecek olursa, bunların en dikkat çekici olan yanı konularındaki çeşitliliktir. Aşağıda verilen listede açıkça görüleceği üzere yaylacılık, karst, araştırma yöntemleri, öğretim yöntemleri, hidrografya, jeopolitik, teknolojik gelişmelerin coğrafyada uygulanabilirliği, çevre ve çevre koruma, uygulamalı coğrafya gibi pek çok farklı konuyu ele alan yayınlarının yanı sıra, mesleki olaylar da hep değindiği konular arasında olmuş, ayrıca çeşitli ansiklopedi maddeleri de yazmıştır. Burada, hocanın tüm yayınları hakkında ayrıntılı bilgi verilmeyecek, sadece iki konuya odaklanmış olan yayınlarına kısaca değinilecektir.

Hocanın yayınları içerisinde yaylacılık ile ilgili olanlardan öncelik ve özellikle söz etmek gerekir. Çünkü uzun yıllar Anadolu'nun pek çok kesimini dolaşarak yaptığg araştırmalarda derlediği bilgileri kullanıp, sonuçlarının ortaya konduğu bu çalışmalar ulusal ve uluslararası ortamlarda sunulmuş ve bir bölümü yayın haline getirilmiştir. $\mathrm{Bu}$ çalışmaların, yaylacılık konusunda ülkemiz araştırmacılarının ilk yayınları olması bakımından da ayrı bir yeri ve önemleri vardır. Burada ayrıca belirtmek gerekir ki, doçentlik sunusu amacıyla yaptığı çalışmaların sonuç raporu mahiyetindeki metni hocanın vefatından sonra yayınlanabilmiştir ${ }^{16}$. 
Mutlaka değinilmesi gereken ikinci grup yayınlar ise karst ile ilgili olanlardır. Karst konusunda ilk olarak Türk Coğrafya Dergisinde bir makale yayınlamış, ardından konuyu daha ayrıntılı olarak ele aldığı çalışmasını aynı adla Türk Coğrafya Kurumunun ilk yayını olarak 1944 yılında kitaplaştırmıştır. Hocanın karst konusundaki bir diğer ilki de dünyanın ve ülkemizin en geniş jips karstı oluşumlarının bulunduğu alanlardan birisi olan Sivas ve çevresinde görülen jips karstı hakkındaki araştırmalarının bulgularını sunduğu kitabıdır.

\section{Son Söz}

Yukarıda yazılanlar açıkça göstermektedir ki Cemal Arif Alagöz, tüm hayatı boyunca mesleğini ön planda tutmuş, onun gelişmesi için çaba sarf etmiş müstesna bir bilim insanıdır. Kurucuları arasında olduğu bölümün öğrencileri başta olmak üzere ülkemiz coğrafyacıları onun bu gayretini görür, idrak eder, özenir ve öykünürlerse eminiz ki ruhu şad olacaktır.

\section{Prof. Cemal Arif Alagöz’ün Bilimsel Çalışmaları}

1926, Cumhuriyet Çocuklarına (Yeni) Coğrafya Dersleri (3. Sınıf). (Mehmet Besim [Darkot] ile birlikte), (19. Baskıs1 1942) İstanbul.

1926, Cumhuriyet Çocuklarına (Yeni) Coğrafya Dersleri (4. Sınıf). (Mehmet Besim [Darkot] ile birlikte), (19. Baskis1 1942) İstanbul.

1926, Cumhuriyet Çocuklarına (Yeni) Coğrafya Dersleri (5. Sınıf). (Mehmet Besim [Darkot] ile birlikte), (19. Baskıs1 1942) İstanbul.

1936, "Demir Sanayii” Ülkü, Cilt: 6 Sayı: 35, s. 352-365, Ankara.

1938, Anadolu'da Yaylac1lık. CHP Yayın1, Seri: 1, Kitap: 25, Ankara.

1938, "Sur la Transhumance en Anatolie, Particulièrement au Nord d'Ankara" IGU, Comptes Rendus du Congrès International de Géographie Amsterdam, 1938, Tome III.A, s. 5-10, Leiden.

1938, "Şehir Coğrafyası" Belediyeler Dergisi, S: 34, Ankara.

1939, “15. Uluslararası Coğrafya Kongresi (Amsterdam 1938)" Oluş Dergisi, C. 1, S. 7, s. 107-108, Ankara.

1939, “15. Uluslararası Coğrafya Kongresi (Amsterdam 1938)” Oluş Dergisi, C. 1, S. 8, s. 125-127, Ankara.

1939, “15. Uluslararası Coğrafya Kongresi (Amsterdam 1938)” Oluş Dergisi, C. 1, S. 9, s. 140-141, Ankara.

1939, “15. Uluslararası Coğrafya Kongresi (Amsterdam 1938)” Oluş Dergisi, C. 1, S. 10, s. 158-159, Ankara.

1939, “15. Uluslararası Coğrafya Kongresi (Amsterdam 1938)” Oluş Dergisi, C. 1, S. 11, s. 172-174, Ankara.

1939, “15. Uluslararası Coğrafya Kongresi (Amsterdam 1938)” Oluş Dergisi, C. 1, S. 12, s. 184-185, Ankara.

1939, “15. Uluslararası Coğrafya Kongresi (Amsterdam 1938)” Oluş Dergisi, C. 1, S. 13, s. 205-206, Ankara.

1939, "Resimlerle Türkiye”, İlköğretim Dergisi, Say1: 26, 27, 28, 31, 34 ve 36, Ankara.

1941, "Yayla Tabiri Hakkında Rapor" Birinci Coğrafya Kongresi, Raporlar, Müzakereler, Kararlar, Maarif Vekilliği Yayını, s. 150-157, Ankara.

1942, “Coğrafya Öğretimi” İlköğretim Dergisi, Sayı: 101, Ankara.

1943, "Faik Sabri Duran'ın Hayatı” Ulus Gazetesi 10 Mayıs 1943, Ankara.

1943, "Coğrafya Olayları” Ankara Üniversitesi Dil ve Tarih-Coğrafya Fakültesi Dergisi, C: I, Say1: 5, s. 195-200, Ankara.

1943, "II. Dünya Harbi Kartoğrafya ve Kuzey Kutup Memleketleri (Tercüme)” İlköğretim Dergisi, Say1: 131, 132, 133, 134, Ankara. 
1943, “Türkiye'de Karst Olayları Hakkında Bir Araştırma” Türk Coğrafya Dergisi Sayı: 1, s. 86-92, Ankara.

1943, “Türk Coğrafya Kurumunun Amaçları ve Çalışmaları (Rapor)” Türk Coğrafya Dergisi, Sayı: 34, s. 397-406, Ankara.

1944, Türkiye Karst Olayları Hakkında Bir Araştırma. Türk Coğrafya Kurumu Yayınları Sayı: 1, Ankara.

1944, "Coğrafya Bakımından Yurt Araştırmaları” Ankara Üniversitesi Haftası Kars, s. 68-76, Ankara.

1944, "Coğrafya Gözüyle Hatay” Ankara Üniversitesi Dil ve Tarih-Coğrafya Fakültesi Dergisi, C: II, Say1: 2, s. 203-216, Ankara.

1944, "Hatay Vilayeti Coğrafyası" Aylık Ansiklopedi, C: 1, s. 50-53, İstanbul.

1944, "Macaristan Coğrafyası" Aylık Ansiklopedi, C: 1, s. 117-119, İstanbul.

1945, "III. Coğrafya Haftası İzmir'de Nasıl Geçti” Ulus Gazetesi 13 Ekim 1945, Ankara.

1945, "Üçüncü Coğrafya Meslek Haftası” Ankara Üniversitesi Dil ve Tarih-Coğrafya Fakültesi Dergisi, C. IV, Say1: 1, s. 150-151, Ankara.

1946, “Ankara Çevresi Coğrafya Köy Monografyası İçin” Ankara Üniversitesi Dil ve Tarih-Coğrafya Fakültesi Dergisi, C: IV, Say1: 4, s. 409-427, Ankara.

1947, "Deprem, Seylâplar ve Meteoroloji İşleri” Ankara Üniversitesi Dil ve Tarih-Coğrafya Fakültesi Dergisi, C: V, Sayı: I, s. 45-59, Ankara.

1947, "Dördüncü Coğrafya Meslek Haftası, Birinci Jeoloji İlmi Toplantısı" Ankara Üniversitesi Dil ve Tarih-Coğrafya Fakültesi Dergisi, Cilt: V, Sayı: 3, s. 329-338, Ankara.

1948, "Türkiye Jeoloji Kurumu II. İlmi Toplantısı" Ankara Üniversitesi Dil ve Tarih-Coğrafya Fakültesi Dergisi, C: VI, S: 1-2, s. 85-86, Ankara.

1949, "Üstat Saffet Geylangil” Türk Coğrafya Dergisi, Sayı: 6-7, s. 11-12, Ankara.

1950, "Bir Geziden Müşahedeler” Türkiye Jeoloji Kurumu Bülteni, Cilt: II, Sayı: 2, s. 72-74, Ankara.

1951, "Coğrafya Öğretiminde Film” Film ve Öğretim Dergisi, Say1: 6-7, s. 8-9, 11, İstanbul.

1951, "Types de Migration Estivale en Turquie" IGU, Comptes Rendus du Congrès International de Géographie Lisbonne 1949, Tome III, Travaux de la Section IV, s. 9-10, Lisbonne.

1951, "L'estivage en Anatolie Méridionale" IGU, Comptes Rendus du Congrès International de Géographie Lisbonne 1949, Tome III, Travaux de la Section IV, s. 11, Lisbonne.

1955, "İmar Planlarında Çocuk Bahçeleri” İller ve Belediyeler Dergisi, Sayı: 116, s. 347-349, Ankara.

1955, “Unesco Nedir?” Eğitim Haberleri, Sayı: 1, s. ? Ankara.

1959, “Coğrafya Gözü ile Kıbrıs” Türk Coğrafya Dergisi, Sayı: 18-19, s. 1-15, İstanbul.

1959, "Coğrafya Haberlerini Takdim” Coğrafya Haberleri, Say1: 1, s. 1, Ankara.

1959, "Uçak Devri ve Coğrafya" Coğrafya Haberleri, Sayı: 2, s. 1-5, Ankara.

1964, “Ankara Yakın Kuzeyinde Ovacık Çanağı ve Ayvalı Boğazı” Türk Coğrafya Dergisi, Sayı: 2223, s. 1-16, Ankara.

1966, "Coğrafyacı Gözü İle Türkiye'de Tabiatı Koruma” Milli Parklar ve Tabiatın Korunması Seminerleri: IV, Tebliğ 9, s. 1-17, Ankara.

1966, "Yaylalarımız, Yaylacılık ve Turistik Yönleri” Dağ Turizm Semineri Konuşma Metinleri, s. 19, Turizm ve Tanıtma Bakanlığı Etüd ve Planlama Dairesi Yayını. Ankara.

1966, "İktisadi Coğrafya ve İktisadi Kalkınma” Ankara Üniversitesi Siyasal Bilgiler Fakültesi Dergisi, Cilt: XXI, Sayı: 2, s. 39-48, Ankara.

1966, "Kızılırmağın Suyu" Ankara Üniversitesi Dil ve Tarih-Coğrafya Fakültesi, Coğrafya Araştırmaları Dergisi, Sayı: 1, s. 1-16, Ankara.

1967, Sivas Çevresi ve Doğusunda Jips Karstı Olayları. Ankara Üniversitesi Dil ve Tarih-Coğrafya Fakültesi Yayınları No: 175, Ankara.

1967, “Coğrafya Gözü ile Tabiatı Koruma” Türkiye Tabiatını Koruma Cemiyeti Yay. No:10, Ankara.

1968, "L'utilité Pratique de la Géographie et les Travaux Intéressant Cette Discipline dans l'administration en Turquie" Les Congres et Colloques de l'Université de Liege Volume: 48, Colloque International de Géographie Applique, s. 95-105, Liege.

1968, “Türk Coğrafya Kurumu VIII. Türk Coğrafya Kongresi ve XVIII. Meslek Haftası Açılış 
Konuşması" Türk Coğrafya Dergisi, S: 24-25, s. III-VIII, Ankara.

1971, "Kıbrıs Tarihine Coğrafi Bakış” Milletlerarası Birinci Kıbrıs Tetkikleri Kongresi (14-19 Nisan 1969) Tebliğler Kitabı, Türk Kültürünü Araştırma Enstitüsü Yay: 36, Seri I, Sayı: A2, s. 13-29, Ankara.

1971, "Introduction Géographique a l'Historie de Chypre" Milletlerarası Birinci Kıbrıs Tetkikleri Kongresi (14-19 Nisan 1969) Tebliğler Kitabı, Türk Kültürünü Araştırma Enstitüsü Yayını: 36, Seri I, Say1: A2, s. 31-39, Ankara.

1972, "Ülkeler Coğrafyası Yakın Çevre Etüdleri Hakkında Açıklama” Ankara Üniversitesi Dil ve Tarih-Coğrafya Fakültesi, Coğrafya Araştırmaları Dergisi, Sayı: 5-6, s. 7-26, Ankara.

1973, "Karst Olayları Üzerine Yeni Bir Müşahede 'Antalya Liman Koyağı"” Jeomorfoloji Dergisi, Say1: 5, s. 33-42, Ankara.

1975, "Dil ve Tarih-Coğrafya Fakültesi Kuruluşundan 1973 Yılına Kadar, Ülkeler Coğrafyası Kürsüsü Çalışmaları Hakkında” Türk Kültürünü Araştırma Enstitüsü, Y11: XI-XIV, s. 214-269, Ankara.

1975, “Tıbbî Coğrafya ve Ankara'da Hava Kirlenmesi” Acta Oncologica Turcica, Cilt: 8, Sayı: 1-2, s. 22-33, Ankara.

1984, “Türkiye Yer Adları Üzerine Bazı Düşünceler” Türk Yer Adları Sempozyumu Bildirileri (1113 Eylül 1984), Kültür ve Turizm Bakanlığı Milli Folklor Araştırma Dairesi Yay: 60, Seminer, Kongre Bildirileri Dizisi: 17, s. 11-23, Ankara.

1993, "Türkiye'de Yaylacılık Araştırmaları" Ankara Üniversitesi Türkiye Coğrafyası Araştırma ve Uygulama Merkezi Türkiye Coğrafyası Dergisi, Sayı: 2, s. 1-51, Ankara.

\section{Notlar:}

${ }^{1}$ Sözü edilen belge $\mathrm{H}$. Tunçel arşivindedir.

2 İ. Yalçınlar, hocanın Barbaros Nümune Mektebindeki öğretmeni ve aynı zamanda okul müdürü olan Ahmet Halit'i hiç unutmadığını, adının bir sokağa verilmesini önerdiğini belirtmiştir (Yalçınlar, 1993: 5), Ahmet Halit [Yaşaroğlu] (1891-1951) tarih-coğrafya öğretmeni, yazar ve yayıncıdır.

${ }^{3}$ Alagöz’ün vefatının ardından kaleme alınan bir yazıda, hocanın, İstanbul Erkek Muallim Mektebinde (Erkek Öğretmen Okulu) eğitim gördüğü dönemde, Cumhuriyet döneminde uzun yıllar Talim-Terbiye Kurulu başkanlığında bulunmuş değerli eğitimci İhsan Sungu, tarihçi ve edebiyatçı İbrahim Alaettin Gövsa ve kendisinde silinmez izler bırakmış Selim Sırrı Tarcan gibi tanınmış hocalardan feyz aldığı özellikle vurgulanmıştır (Yücel, 1994: 206), bu durum muhtemelen hocanın Yücel ile yaptığı sohbetlerden arda kalan bir bilgi niteliğindedir.

${ }^{4}$ Tuncel, M. 1991: 3, dip not no:8 ve Tuncel, M. 1992: 4, dip not no:8

${ }^{5} 1907$ İstanbul doğumlu olan Fatma Zehra hanımın babası Millî Eğitim Bakanlığı müfettişlerinden (Yalçınlar, 1993: 3) Hasan Tahsin beydir, annesi Emine Nahye Hanım'dır. Cemal Arif ile Fatma Zehra 1932 yılında evlenmiştir. Fatma Zehra Hanım Cemal Arif Alagöz hocadan birkaç yıl sonra, 1995'de, Ankara'da vefat etmiş ve Cebeci Asri Mezarlığında eşinin yanına defnedilmiştir.

${ }^{6}$ Köşeli parantez içi bilgiler yazarlar tarafindan ilave edilmiştir.

${ }^{7} \mathrm{Bu}$ toplantılardan birisine ait bazı fotoğraflar vefatı sonrasında İsmail Yalçınlar tarafından hoca hakkında hazırlanan bir anma yazısında kullanılmıştır (Yalçınlar, 1993: 2).

${ }^{8}$ Bu konuda ayrıntılı bilgi için ayrıca bkz. Tunçel ve Üçeçam 2000: 231-251.

${ }^{9}$ Bu konuda ayrıca bkz. Yiğit ve Tunçel, 2017: 81.

${ }^{10} \mathrm{Bu}$ ve devamında yer alan yazışma metinlerinin tümü $\mathrm{H}$. Tunçel arşivindedir.

${ }^{11}$ Bir dönem ismi Türkiye Mağara Araştırma, Tanıtma ve Turizm Derneği olmuştur, günümüzdeki adı ise Mağara Araştırma Derneğidir.

12 Türkiye Meteoroloji Kurumu 1959’da lağvedilmiş ve maddi varlığı Türk Coğrafya Kurumuna devredilmiştir.

${ }^{13}$ Sözü edilen harita H. Tunçel arşivindedir.

${ }^{14}$ Cemal Arif Alagöz'ün yurtiçi seyahatleri ile ilgili ayrıntılı bilgi edinmek için bkz. Alagöz 1975, Tunçel ve Üçeçam 2000.

${ }^{15}$ Meslek haftalarında sunulan ancak yayınlanmayan çalışmaları için bkz. Tunçel ve Üçeçam 2000

${ }^{16} \mathrm{Bu}$ konuda ayrıca ve çeşitli detaylı bilgiler için bkz. Tunçel, 2015: 8, 10 ve 2016: 447, 449-450. 


\section{Teşekkür}

Osmanlı Türkçesi ile hazırlanmış bazı belgelerin okunmasında yardımları olan Bilecik Şeyh Edebali Üniversitesi öğretim üyeleri Prof. Dr. İlhami Yurdakul ve Doç. Dr. Refik Arıkan’a teşekkür ederiz, onların desteği olmasa yukarıdaki metnin pek çok bilgiden mahrum kalacağı aşikârdır.

\section{Referanslar/References}

Akkan, E. (1998). Dil ve Tarih-Coğrafya Fakültesi'nin kuruluşunun 60. yıldönümünde coğrafya bölümü. Türkiye'de Sosyal Bilimlerin Gelişmesi ve Dil ve Tarih-Coğrafya Fakültesi Sempozyumu, Bildiriler Kitabı içinde (295-313). Ankara.

Alagöz, C. A. (1975). Dil ve Tarih-Coğrafya Fakültesi kuruluşundan 1973 yılına kadar, ülkeler coğrafyası kürsüsü çalışmaları hakkında. Türk Kültürünü Araştırma Enstitüsü, Türk Kültürü Araştırmaları, XI/XIV (1973-1975), 214-269.

Anonim (1943). Türk Coğrafya Kurumu Yasas1. Türk Coğrafya Dergisi, I (I), 108-112.

Anonim (1949). Türkiye Jeoloji Kurumu üyeler listesi. Türkiye Jeoloji Kurumu, II (1), 148-151.

Cemal Arif Alagöz hakkında, 1917-1987 dönemine ait pek çok belge (H. Tunçel arşivi)

Erinç, S. (1973). Cumhuriyet'in 50. Yılında Türkiye'de Coğrafya. Ankara: Başbakanlık Kültür Müsteşarlığı Cumhuriyetin 50. Y1ldönümü Yayınları: 11.

Ertek, T. A., Özbakan, F. (2012). Türk Coğrafya Kurumu Tarihçesi. İstanbul: Türk Coğrafya Kurumu Yayını No: 7.

Kayan, İ. (1992). Türk coğrafyacıları bir büyüğünü daha yitirdi: Prof. Cemal Arif Alagöz (1902-1991), Ege Coğrafya Dergisi, 6 , numarasiz sayfa.

Köksal, A. (1993). Prof. Cemal Arif Alagöz'ün hayatı, Ankara Üniversitesi Türkiye Coğrafyası Araştırma ve Uygulama Merkezi Türkiye Coğrafyası Dergisi, 2, VII-XII.

Maarif Vekilliği (1941). Birinci Coğrafya Kongresi, Raporlar, Müzakereler, Kararlar. Ankara.

Özçağlar, A. (2020). Türkiye'de coğrafya literatürünün gelişmesinde Dil ve Tarih-Coğrafya Fakültesi coğrafya bölümünün rolü ve önemi, Türkiye Araştırmaları Literatür Dergisi, 18 (35), 215-254.

Tuncel, M. (1991). Ord. Prof. Dr. Besim Darkot'un hayatı ve Türkiye coğrafyasına katkıları, Atatürk Kültür, Dil ve Tarih Yüksek Kurumu, Coğrafya Araştırmaları Dergisi, 3, 1-13.

Tuncel, M. (1992). Coğrafya dolu bir hayat: Ord. Prof. Dr. Besim Darkot, Türk Coğrafya Dergisi, 27, 1-14.

Tunçel, H. (2014). Türk coğrafyacılarının yayın performansı üzerine. E. Bekaroğlu, A. R. Özdemir (Ed.) Bir Disiplinin İ̧̧ Dünyası: Modern Türk coğrafyası üzerine söyleşiler içinde (365-381). İstanbul.

Tunçel, H. (2015). Coğrafyanın yaylacılık literatürü üzerine bir değerlendirme. Yayla Kültürü ve Yaylacılık Sempozyumu 6-7 Kasım 2014, Bilecik, (Ed. H. Tunçel) s. 5-26, Bilecik Şeyh Edebali Üniversitesi, Sempozyum ve Konferanslar Serisi: 8 , İstanbul.

Tunçel, H. (2016). Coğrafyada yaylacılık araştırmaları. R. Arıkan, H. Demiryürek (Ed.) Bir Insan-ı Selim, Prof. Dr. Azmi Özcan'a Armağan içinde, Lotus Yayınevi, 95, 443-469, İstanbul.

Tunçel, H., Üçeçam, D. (2000). Türk Coğrafya Kurumu meslek haftaları, Firat Üniversitesi Sosyal Bilimler Dergisi, 10 (2), 231-251.

Tunçel, H., Yiğit, A., Çelikbağ, S. (2010). Türkiye Coğrafya Bibliyografyası, Kitaplar ve Makaleler. Ankara: Bilecik Üniversitesi Yayınları No: 2.

Tümertekin, E. (1998). Beşeri Coğrafya. Cumhuriyet Döneminde Türkiye'de Bilim: Sosyal Bilimler-II içinde (187-215) TÜBA, Ankara.

Yalçınlar, İ. (1993). Profesör Cemal Arif Alagöz (1902-1991) hayatı ve mesleki çalışmaları, Türk Coğrafya Dergisi, 28, 1-15.

Yiğit, A., Tunçel, H. (2017). 100. Yılında Türkiye’de Coğrafyacılar, Türkiye Coğrafyacı Biyografileri (1915-2015). (Say1: 8) Bilecik: Türk Coğrafya Kurumu Yayınları.

Yücel, T. (1994). Coğrafya alimi Prof. Dr. Cemal Arif Alagöz’ün ardından, Türk Kültürünü Araştırma Enstitüsü, Türk Kültürü Dergisi, 372, 206-209. 